\title{
HUKUM DAN PENGELOLAAN LIMBAH BAHAN BERBAHAYA DAN BERACUN (B3) WILAYAH PERBATASAN NEGARA DI KEPULAUAN RIAU
}

\author{
Ukas $^{1}$, Zuhdi Arman ${ }^{2}$ \\ Program Studi Ilmu Hukum, Fakultas Ilmu Sosial dan Hukum, Universitas Putera Batam \\ Jalan R. Soeprapto Muka Kuning, Kibing, Kec. Batu Aji, Kota Batam, Kepulauan Riau \\ ${ }^{1}$ Ukasibrahim@gmail.com, ${ }^{2}$ Zuhdiarman1@gmail.com
}

\begin{abstract}
Hazardous and toxic waste (B3) is waste generated from a production process both industrial and other business activities, where the people who live there are usually found or produce waste, waste water or other activities that are not well managed will have an impact on creatures and the environment around it, because of its nature and concentration, both directly and indirectly, can damage the environment and the health of living things around it. The method used in this research is normative juridical. The results of the study show that pollution, hazardous and toxic substances (B3) can occur anytime and anywhere, whether carried out by industry or other business activities to take advantage without thinking about mistakes caused by these activities, the arrangement and environmental habitat are damaged due to environmental damage and which do not less important is the emergence of hazardous and toxic substances, which must be fought to maintain the development of a beautiful and environmentally friendly environment for now and for generations to come.
\end{abstract}

Keymords:Waste; dangerous; Poisonous; Border.

\begin{abstract}
Abstrak, Limbah bahan berbahaya dan beracun (B3) adalah buangan yang dihasilkan dari suatu proses produksi baik industri maupun kegiatan usaha lainnya, dimana masyarakat bermukim disana biasa didapati atau menghasilkan sampah, air buangan atau aktivitas lainnya yang tidak terkelola dengan baik akan menimbulkan dampak bagi makhluk dan lingkungan disekitarnya, karena sifat dan konsentrasinya baik langsung maupun tidak dapat merusak lingkungan dan kesehatan mahluk hidup disekitarnya. Metode pendekatan yang digunakan dalam penelitian ini adalah yuridis normatif. Hasil penelitian memperlihatkan pencemaran, bahan berbahaya dan beracun (B3) bisa saja terjadi kapan dan dimana saja baik dilakukan oleh industri dan kegiatan usaha lainnya untuk mengambil keuntungan tanpa memikirkan kesalahan akibat kegiatan tersebut, penataan dan habitat lingkungan itu rusak karena terjadinya kerusakan lingkungan dan yang tak kalah penting munculnya bahan berbahaya dan beracun, yang harus diperangi untuk menjaga pembangunan lingkungan yang asri dan berwawasan lingkungan untuk saat ini dan saat generasi yang akan datang.
\end{abstract}

Kata Kunci:Limbah; Berbahaya; Beracun; Perbatasan. 


\section{Pendahuluan}

Dalam perkembangan sejak kemerdekaan sampai dengan sekarang ini Indonesia merupakan Negara demokrasi yang menerapkan hukum. ${ }^{1}$ Hukum Lingkungan merupakan suatu kajian tentang tata alam, ilmu ini tergolong baru dipelajari khususnya di Indonesia. Berbicara hukum lingkungan berarti berbicara tentang sumber daya alam dan peraturan hukum yang mengaturnya, baik yang meliputi tata hukum lingkungan, perlindungannya, kesehatan lingkungan, maupun perselisihan lingkungan. Dalam tulisan ini penulis secara umum mengedepankan kepada hukum pengelolaan pencemaran lingkungan yang bisa berakibat lebih jauh karena selainkerusakan lingkungan (kesehatan lingkungan) juga menimbulkan bahaya yang ditimbulkan yakni secara khusus adanya yang dikenal bahan berbahaya dan beracun (B3).

Menurut Drupsteen bahwa "hukum lingkungan(milieurecht) adalah "hukum yang berhubungan dengan lingkungan alam (natuurlijkmilieu) dalam arti luas, ruanglingkupnya berkaitan dengan ruangpengelolaan lingkungan, dengan demikian hukum lingkungan merupakan instrument-instrumen yuridis bagi pengelolaan lingkungan"2lebih lanjut St. Moenadjat Danussaputro membedakan antar hukum lingkungan modern yang berorientasi kepada lingkunganatau (environment-oriented law) dan hukum lingkungan klasik yang berorientasi kepada penggunaan lingkungan atau (use-oriented law) ${ }^{3}$,yang dalam penulisan ini lebih mengarah kepada hukum lingkungan klasik yang berorintasi secara khusus kepada penggunaan lingkungan yaitu pengelolaan pencemaran dan bahan berbahaya dan beracun (B3) yang membahayakan lingkungan dan kesehatan mahluk hidup terutama manusia dan sekitarnya.

Beberapa Peraturan perundang-undangan yang mengatur lingkungan (perlindungan hukum lingkungan) mulai dari Undang-Undang Nomor 4 Tahun 1984 bahkan sampai pada perubahan yang terakhir dengan Undang-Undang Nomor 32 Tahun 2009 tentang Perlindungan dan Pengelolaan lingkungan hidup (UUPPLH). Perlindungan yang termaktub dalam Undang-Undang tersebut meliputi perlindungan sumber daya alam hayati dan sumber daya alam non hayati dan ekosistemnya, bahwa perlindungan hukum itu dilakukan berdasarkan Baku Mutu Lingkungan (BML) dan sebagainya.

Lingkungan Hidup Sebagai Kesatuan Ruang, dan Lingkungan hidup sebagai kesatuan ruang dengan semua benda. Hukum lingkungan sebagai kesatuan ruang semua benda, daya, makhluk hidup, termasuk manusia dan perilakunya bagitu mempengaruhi alam itu sendiri. Dalam ilmu ekologi (ilmu tentang makhluk hidup di dalam rumah tangganya), artinya setiap makhluk hidup berada dalam suatu proses penyesuaian diri (adaptasi) dalam sistem kehidupan yang dipengaruhi oleh asas-asas dalam kelangsungan perikehidupan ekologi tersebut. Menurut Nursid Sumaatmadja bahwa"asas dari ekologi dapat diklasifikasikan atas 3 (tiga) yaitu asas keanekaragaman, kerjasama, persaingan,

\footnotetext{
${ }^{1}$ Zuhdi Arman, Tinjauan Terhadap Sistem Multi Partai Dalam Sistem Pemerintahan Presidensial Di Indonesia Pada Era Reformasi, Jurnal Cahaya Keadilan, Vol 6, No.1, April 2018, hlm.23

${ }^{2}$ Grusteen, yang dikutip Muhammad TaufikMakarau, Aspek-AspekHukumLingkungan, (Jakarta: PT. Indeks, 2011), hlm. 3.

${ }^{3}$ St. MoenadjatDanussaputro, HukumLingkungan, (Bandung: Bina Cipta,1979), hlm 35-37.
} 
intraksi dan asas keseimbangan ${ }^{4}$. Dalam sistem peri kehidupan ekologi tersebut diperlukan pengaduan yang berwujud penetapan nilai-nilai dalam kehidupan dan pengelolaan lingkungan hidup melalui pendekatan norma-norma hukum lingkungan.

Indonesia dengan Undang-Undang lingkungan yang ada dari Undang-Undang Nomor 4 Tahun 1982 tentang Kesatuan Ketentuan Pokok Lingkungan Hidup (UULH) yang kemudian diubah dengan Undang-Undang Nomor 23 tentang Pengelolaan Lingkungan Hidup (UUPLH) yangmengenal dua bentuk masalah-masalah lingkungan hidup yaitu pencemaran lingkungan hidup dan perusakan lingkungan hidup sebagaimana dalam Pasal 1 butir (2 ) Undang-Undang Nomor 23 Tahun 1997 yakni masuknya atau dimasukannyamakhluk hidup, zat, energy dan atau komponenlain kedalam lingkungan hidup, oleh kegiatan, sehinggakualitasnya turun sampai ketingkat tertentu yang menyebabkan lingkungan hidup tidak berfungsi lagi sesuai dengan peruntukannya. Dalam perkembangan berikutnya Undang-Undang Nomor 23 Tahun 1997 menjadi UndangUndang Nomor 32 Tahun 2009 dalam Pada Pasal 1 butir 12 dipertegas dan menambah kelimat akibat dari rusaknya lingkungan itu salah satu sebab karena terjadi pencemaran yang membawa akibat hal negatif dengan munculnya bahan berbahaya dan beracun (B3), dari Pasal tersebut perlunya pengelolaan lingkungan hidup yang sesuai dengan Peraturan perundang-undangan lingkungan hidup terutama di wilayah air yang meliputi (danau, sungai, pantai dan laut) tanpa membedakan wilayah udara, darat, dan laut (terutama wilayah laut perbatasan negara (Kepri) khususnya.

Pembangunan terhadap ekologi di ukur menurut besar kecilnya penyimpangan dari batas-batas yang ditetapkan sesuai komponen atau daya tenggap ekosistem lingkungan, kemampuan lingkungan atau daya ekosistem lingkungan tersebut dikenal dengan istilah daya dukung lingkungan (carrying coacity), adapaun untuk batas-batas daya dukung kemampuan lingkungan disebut dengan istilah nilai ambang batas (NAB). Menurut Muhammad Erwin dalam bukunya Hukum Lingkungan bahwa "nilai ambas batas merupakan batas tinggi (maksimum) dan terendah (minimum) dari kandungan zat-zat, makhluk hidup, atau komponen komponen lain yang diperbolehkan dalam setiap intraksi yang diperkenankan dengan lingkungan, khususnya yang berpotensi mempengaruhi mutu lingkungan. ${ }^{5}$

Pengertian batas mutu lingkungan juga dapat dipahami dari rumusan dalam Pasal 1 angka 3 Undang-Undang Perlindungan dan Pengelolaan Lingkungan Hidup, yakni ukuran batas atau keadaan makhluk hidup, zat, energy atau komponen yang dapat atau harus ada atau unsur pencemaran yang ditegangkan adanya dalam suatu sumber daya bentuk sebagai unsur lingkungan hidup.

Pemerintah telahmelakukan berbagaiupaya penanggulangan, ${ }^{6}$ Pencemaran Lingkungan dan Pengelolaan Limbah bahan berbahaya dan beracun (B3). Didalam Undang-Undang Nomor 4 Tahun 1982, Undang-Undang Nomor 23 Tahun 1997 dan

\footnotetext{
${ }^{4}$ R. M. Gatot P. Soemartono, HukumLingkungan Indonesia, (Jakarta: SinarGrafika,1996),hlm. 37. ${ }^{5}$ Muhamad Erwin, HukumLingkunganDalamSistemPerlindungandanPengelolaanLingkunganHidup di Indonesia. (Jakarta: RafikaAditama, 2015), hlm. 49.

${ }^{6}$ Jevlin Solim, Upaya Penanggulangan Tindak Pidana Penipuan Situs Jual Beli Online Di Indonesia, Jurnal Hukum Samudra Keadilan, Vol 14, No.1, 2019, hlm 106.
} 
direvisi dengan Undang-Undang Nomor 32 Tahun 2009 tentang PPLH dimana dalam Pasal 17 penulis pahami bahwa ketentuan-ketentuan yang mendasar pencegahan akibat sudah dan terjadinya pencemaran lingkungan dan penanggulangan perusakkan secara integral beserta beberapa peraturan lainnya. Untuk pencemaran dari segi pengawasannya harus dilakukan secara sunguh-sungguh (secara sektoral). Hal ini telah ditetapkan dari berbagai Perurutan perundang-undangan lainnya yang ada termasuk penegakan hukum lingkungan itu sendiri ${ }^{7}$.

Bagi pelaku usaha golongan ekonomi lemah yang usahanya diperkirakan telah dan akan merusak materi/fisik lingkungan pelaku usaha tersebut diberi pemahaman masalahperusakakan dan pencemaran lingkungan, agar lingkungan terjaga dari pencemaran dan kerusakannya ${ }^{8}$, sesuai materi Undang-Undang Lingkungan Hidup Nomor 32 Tahun 2009.Izin Pengelolaan Limbah Bahan Beracun dan Berbahaya (B3). Izin pengoprasian pengelolaan limbah bahan beracun dan berbahaya (B3)diatur dalam Peraturan Pemerintah No. 18 Tahun 1999 tentang Pengelolaan Limbah B3 meliputi penyimpanan, pengumpulan, pemanfaatan, pengolahan dan penimbunan. Izin pengoperasian ini dikeluarkan oleh Kepala BAPEDAL. Bahan yang karena sifatnya daan konsentrasi, jumlahnya baik langsung maupun tidak langsung dapat mencemarkan dan merusak lingkungan lingkungan hidup, kesehatan, kelangsungan hdup manusia serta mahluk lainnya. Bahan beracun dan berbahaya (B3) yang merupakan sisa usaha dan kegiatan yang mengandung bahaya karena ia bisa berakibat racun dapat mencemarkan juga lingkungan hidup, membahayakan lingkungan, kesehatan mahluk lainnya. Limbah bahan beracun dan berbahaya (B3) dapat dikategorikan sebagai limbah jika setelah melalui uji karekteristik limbah itu memiliki karakter atau sifat-sifat antara lain mudah meledak, bersifat reaktif dan beracun serta menyebabkan infeksi.

Berdasarkan uraian tersebut, menarik untuk ditelusuri lebih lanjut bagaimana pengaturan hukum dan pengelolaan limbah B-3 wilayah perbatasan negara terkait upaya pengelolaan pencemaran bahan berbahaya dan beracun (B3) di wilayah perairan perbatasan khususnya di Kepulauan Riau.

\section{Metode Penelitian}

Metode dalam melaksanakan suatu penelitian, penulis membutuhkan sebuah metode dalam bentuk desain penelitian dalam hal penggunaannya kualitatif tentunya penulisan ini akan menentukan dan menyesuaikan. Dalam hubungan desain penelitian, dalam penyusunan dan melakukan karya ilmiah ini tentunya menggunakan desain penelitian dengan metode kualitatif yang bertolak dari teori yang ada sebagai penjelasan dan berakhir dengan suatu teori ${ }^{9}$. Teknik pengumpulan data berupa pengumpulan bahan refrensi dan dokumen terkait dengan termasuk karya ilmiah lainnya dari beberapa pakar dibidangnya. Analisa data, membuat suatu aturan, memanipulasi, serta menyikapi data sehingga mudah dipahami dan dibaca dalam hal analisa data adalah membagi data atau kelompok atau kategori, kategori yang sesuai dan lengkap, bebas dan terpisah, dalam

\footnotetext{
${ }^{7}$ Takdir Rahmadi. Hukum Lingkungan di Indonesia, (Jakarta: Rajagrafika, 2014), hlm. 135.

${ }^{8}$ Ibid.hlm. 152 .

${ }^{9}$ Muhamad Erwin, Op. cit.hlm. 49.
} 
penulisan karya ilmiah inidiharapkan data yang bersifat deskriptif bersumber dari tulisan atau ungkapan dan tingkah laku yang dapat diobservasi dari manusia. Lokasinya penulis ini memilih wilayah /lingkungan hidup di Kepulauan Riau terutama diwilayah perairan perbatasan Negara.

\section{Pembahasan}

\section{Hukum Lingkungan Hidup(UUPPLH)}

Undang-Undang yang mengatur tentang perlindungan Lingkungan Hidup diantaranya terdapat dalam Pasal 11-17 Undang-Undang Nomor 4 Tahun 1982. Dalam Pasal tersebut penulis memahami bahwa bertapa pentingnya menjaga lingkungan dari hal-hal yang merusak, mencemari bahkan sampai pada bahaya bahan beracun (B3) terhadap sumber daya alam baik hayati maupun non hayati. Hal tersebut selain pengaturan lingkungan itu sendiri juga perlunya instrument atau ketentuan-ketentuan lain berupa ketentuan konservasi sumber daya alam sesuai Pasal 12 Undang-Undang Nomor 4 Tahun 1984, ketentuan perlindungan sumber daya buatan ditetapkan dengan UndangUndang (Pasal 13). Dari ketentuan-ketentuan yang diutarakan/dikemukaknan di atas juga terkait dengan baku mutu lingkungan (BML). Setiap rencana yang diperkirakan mempunyai dampak penting terhadap lingkungan wajib dilengkapi dengan anlisisa, mengenai dampak lingkungan yang pelaksanaannya diatur dengan Peraturan Pemerintah. Ketentuan tentang pencegahan dan penanggulangan perusahan dan pencemaran lingkunganhidup beserta pengawasannya yang dilakukan secara menyeluruh dan atau secara sektoral ditetapkan dengan Peraturan Perundang-Undangan.

Pemerintah memiliki peran dalam mempromosikan tata pemerintahan yang baik , ${ }^{10}$ Dalam hal tersebut di atashubungannya dengan hukum perlindungan atas sumber daya alam nonhayati yang melipiuti hukum perlindungan atas tanah, dalam rangka pelestarian sumber daya manusia, tanah dan air kaitannya dengan pelaksanaan Pasal 15 UndangUndang Pokok Agraria, hukum perlindungan atas air, karena air beserta sumbersumbernya, termasuk kekayaan alam yang terkandung di dalamnya seperti yang dimaksud dalam Pasal 1 angka 3 dan 4. Pasal tersebut dapat dipahami memberi wewenang kepada pemerintah untuk mengelola serta mengembangkan manfaatan air dan atau sumber sumber air agar tidak tercenmar. Menyusun dan mengatur perencanaan teknis pengaturan, menentukan dan mengatur perbuatan-perbuatan orang dan badan hukum dalam persoalan air dan atau sumber- sumber air, menghormati hak yang dimiliki oleh masyarakat Adat setempat, sepanjang tidak bertentangan dengan kepentingan Nasional.

\section{Perlindungan dan Pengelolaan Lingkungan Hidup.}

Berbicara tentang perlindungan dan pengelolaan lingkungan hidup, pengelolaan meliputi "perencanaan, pemanfaatan, pengendalian, pemeliharaan, pengawasan dan

\footnotetext{
${ }^{10}$ Citra, Sukmadilaga, Good Governance Implementation In Public Sector: Exploratory Analysis of Government Financial Statements Disclosures Across ASEAN Countries, Procedia Social and Behavioral Sciences, 2015.
} 
penegakan hukum". Perencanaan atau hukum perencanaan identik hukum administrasi kaitannya dengan pencemarandan identifikasi masalah atau regulasi yang berbentuk atau berkaitan dengan pencemaran wilayah dan pembangunan wilayah lingkungan. Perencanaan itu dipersiapkan dengan mateng, yang penuh tahapan-tahapan terhadap investasi lingkungan termasuk penetapan wilayah, dan penyusunan RPPLH. Perencanaan yang seperti ini akan melahirkan investasi lingkungan hidup, penetapan wilayah dan penyusunan rencana perlindungan dan pengelolaan lingkungan hidup (RPPLH). Pemanfaatan, pemanfaatan dan daya dukung wilayah serta daya tampung lingkungan hidup dengan memperhatikan keberlanjutan proses pembangunan lingkungan itu sendiri.Perencanaan yang dilakukan ini seharusnya harus dituangkan dalam bentuk penyusunan RPPLH secara tertulis untuk memudahkan menelaah dan mempertanggung jawabkan dalam waktu yang telah ditentukan, sedangkan penyusunan RPPLH beserta peraturannya termasuk analisa daya dukung lingkungan berdasarkan UUPPLH tahun 2009 dengan mengedepankan kearifan lokal tanpa mengurangi perubahan yang setiap saat bisa terjadi. Untuk itu RPPLH tersebut tentunya memuat pemanfaatansumber daya alam dan atau daya dukung lingkungan, memelihara dan melindungi kualitastanpa mengabaikan fungsi lingkungan hidup itu sendiri, pemantauan, pengendalian serta pendayagunaan lingkungan serta penyesuan dan atau adaptasi yang teratur terlebih meneghadapi perubahan-perubahan sewaktu-waktu terjadi karena pengaruh iklim yang ada.

Selain apa yang telah diuraikan di atas pemanfatan dan pengendalian pencemaran termasuk kerusakan lingkungan hidup telebih jika tercemar dengan bahan berbahatya dan bercun (B3). Pemanfaatan sumber daya alam dilakukan juga berdasarkan RPPLH beserta daya dukung lainnya berdasarkan ketentuan Menteri yang terkait, sedangkan pengedalainnya pencemaranatau kerusakan lingkungan hidup berdasarkan UUPPLH dilaksanakan dalam rangka pelestarian fungsi lingkungan yang meliputi instrument pencegahan pencemaran dan atau kerusakan lingkungan hidup tentunya harus memuat kajian lingkungan yang strategis, tata ruang, baku mutu lingkungan tetap tidak bisa diabaikan dan lain-lainnya.

\section{Pengendalian Pencemaran Lingkungan Hidup (Air-Laut)}

Salah satu Peraturan yang mencakup tentang pencemaran dan atau perusakan wilayah laut khususnya adalah Peraturan Pemerintah No. 19 Tahun1999, Peraturan Tersebut dipahami bahwa pendekatan seperti perlindungan mutu laut, pencegahan pemecemaran laut, pencegahan perusakan lingkungan laut dan penanggulangan perusakan dan pencemaran laut, prerlindungan mutu air dilakukan melalui langkahlangkah penelitian data mutu air laut, dan kerakteristik kerusakan laut, menjawab kegiatan usaha mengelola limbah air dan limbah padat. Langkah-langkah yang harus dilakukan antara lain melarang perbuatan yang dapat mrenimbulkan kerusakan laut, mewajibkan kegiatan usaha, pencemaran dan perusakan laut dilakukan dengan melalui langkah-langkah mewahjibkan kegiatan usaha menanggung biaya penagnggulangann pencegahan, penanggulangan dan pembayaran ganti rugi Pengendalain pencemaran laut 
dilakukan melalui penggunaan instrumen-instrumen baku mutu air laut, karakteriabaku kerusakan laut, izin melakukan dumping, dan pengawasan.

Pembangunan Pusat Peningkatan Kapasitas Regional di Indonesia dinilai penting untuk meningkatkan upaya penanggulangan pencemaran laut dari aktivitas daratan. Pasalnya, lingkungan laut yang terjaga memiliki peran penting bagi kesejahteraan masyarakat juga untuk mengendalikan perubahan iklim. Utusan Badan Lingkungan Hidup PBB (UNEP) Satya S Tripathi mengatakan, berdasarkan komitmen yang sudah didaftarkan setiap negara berdasarkan Persetujuan Paris, masih akan terjadi peningkatan suhu bumi hingga 3,2 derajat celcius dibandingkan dengan masa pra revolusi industri. Padahal, traktat global untuk pengendalian perubahan iklim itu mengamanatkan agar kenaikan suhu bumi dipertahankan di bawah 2 derajat celcius. "Jadi kita butuh untuk meningkatkan ambisi dan upaya hingga tiga kali lipat dari saat ini. Kalau kita ingin mencapai pengendalian suhu bumi di bawah 1,5 derajat celcius, kita butuh upaya hingga empat kali lipat," ujar Satya saat panel tingkat tinggi di Paviliun Indonesia pada Konferensi Perubahan Iklim (COP UNFCCC) ke- 24 di Katowice, Polandia, Rabu (12/12) waktu setempat.Hadir dalam kesempatan tersebut sejumlah menteri dan pejabat tinggi dari negara-negara yang berada di kawasan AsiaPasifik, seperti Jepang dan negara Kepulauan Seychelles. Satya menjelaskan, salah satu upaya yang mesti terus ditingkatkan adalah pengendalian pencemaran laut dari aktivitas di darat. Ekosistem laut dan pesisir memiliki peran penting dalam pengendalian perubahan iklim menyerap emisi gas rumah kaca (GRK) dan juga menghasilkan oksigen bagi kehidupan. Di sisi lain, perubahan iklim juga mengancam terjadinya kenaikan air laut yang bisa menenggelamkan pesisir dan pulau-pulau kecil. ${ }^{11}$

Terkait eskalasi upaya dalam pengendalian perubahan iklim, Satya menegaskan, perlunya peningkatan kapasitas setiap negara untuk mengendalikan pencemaran laut dari aktivitas di darat. Dia memuji insiatif Indonesia di bawah kepemimpinan Menteri Lingkungan Hidup dan Kehutanan (LHK) Siti Nurbaya yang mendorong dibangunannya Pusat Peningkatan Kapasitas Regional sebagai tempat berbagi pengalaman dan pengetahuan upaya pengendalian pencemaran laut. "Indonesia punya sumber daya, kemampuan dan kemauan. Pusat Peningkatan Kapasitas Regional bisa menjadi tempat bagi negara seperti Indonesia untuk saling berbagi pengalaman dan pengetahuan dalam mengendalikan pencemaran laut," tuturnya. Dia memastikan UNEP akan mendukung sepenuhnya inisiatif Indonesia tersebut. Menteri LHK Siti Nurbaya mengatakan, pemerintah Indonesia menyadari ada tantangan pencemaran laut dari aktivitas di darat. Menurut dia, sekitar $80 \%$ pencemaran laut, seperti sampah plastik, logam berat, dan limbah cair, bersumber dari aktivitas di darat. "Indonesia telah melakukan sejumlah upaya agar pencemaran laut dari aktivitas di darat bisa ditanggulangi," ucapnya. ${ }^{12}$

Menteri LHK menekankan, pencemaran laut bukan saja berdampak buruk bagi keanekaragaman hayati laut tapi juga bagi perekonomian. Pencemaran bisa membuat

\footnotetext{
${ }^{11}$ http://agroindonesia.co.id/2018/12/cegah-perubahan-iklim-pencemaran-laut-harus-dikendalikan/, diakses pada tanggal 11 September 2019.

${ }^{12} \mathrm{https}: / /$ www.beritasatu.com/nasional/527425/tingkatkan-kapasitas-pengendalian-pencemaranlaut, diakses pada tanggal 12 September 2019.
} 
pendapatan nelayan dan masyarakat pesisir jatuh, menggangu sektor pariwisata, dan mengacaukan aktivitas pelayaran. Untuk diketahui, Pembangunan Pusat Peningkatan Kapasitas Regional di Indonesia merupakan hasil pembahasan pada pertemuan antar pemerintah yang ke-4 untuk meninjau implementasi program aksi global demi perlindungan lingkungan laut dari aktivitas berbasis lahan (The 4th Intergovermental Review Meeting on the Implementation of the Global Programme of Action for the Protection of the Marine Environment from Land-Based Activities/IGR-4).

Pertemuan itu menghasilkan Deklarasi Bali yang mengandung dua isu utama, yaitu meningkatkan pengarusutamaan pada perlindungan ekosistem laut dan pantai, terutama dari ancaman lingkungan yang disebabkan peningkatan zat kimia, air limbah, sampah laut, dan mikroplastik. Isu lainnya adalah peningkatan kapasitas, pemahaman dan berbagi pengetahuan melalui kolaborasi dan kerja sama, meliputi pemerintahan, sektor swasta, masyarakat sipil, dan ahli di tingkat regional maupun global dalam perlindungan ekosistem laut dan pantai dari aktivitas berbasis lahan dan sumbersumber polusi. ${ }^{13}$

\section{Pengelolaan Limbah Bahan Berbahaya dan Beracun (B3).}

Pengeloaan limbah di tetapkan berdasarkan Peraturan Pemerintah Nomor 19 Tahun 1994 Yang diperbaharui dengan Peraturan Pemerintah No. 12 Tahun 1995 dan diperbaharui kembali dengan Peraturan Pemerintah No. 18 Tahun 1999 tanggal 27 Februari 1999 yang dikuatkan lagi melalui Peraturan Pemerintah No. 74 Tahun 2001 tanggal 26 November 2001 tentang Pengelolaan Limbah B-3.Menurut Peraturan Pemerintah No. 18 Tahun 1999 yang dimaksud dengan limbah B-3 adalah suatu usaha dan atau kegiatan yang mengandung bahan berbahaya dan beracun yang karena sifat dan konsentrasinya dalam jumlahnya baik secara langsung maupun tidak langsung dapat mencemarkan dan atau merusak lingkungna hidup dan atau membahayakan lingkungan hidup, kesehatan, kelangsungan hidup manusia serta mahluk hidup lainnya.Tujuan pengelolaan limbah B-3 adalah untuk mencegah, menanggulani pencemaran atau kerusakan lingkungan hidup yang diakibtaknya oleh limbah B-3 serta pemulihan kualitas lingkungan yang sudah tercemar sehingga tidak sesuai fungsinya kembali.

Sesuai Peraturan Pemerintah No. 101 Tahun 2014, Peraturan lainnya yang terkait dan analisa sementara bahwa mayoritas industri dan kerajinan masyarakat lainnya belum (tidak) menyadari bahwa limbah tersebut dalam kategori limbah bahan berbahaya dan beracun (B3), sehingga pihak industri dan atau kegiatan lainnya oleh masyarakat akhirnya di buang begitu saja kesistem perairan dan atau tempat lainnya di wilayah darat tanpa adanya proses pengelolaan, yang pada prinsipnya pengelolaan penangan limbah bahan berbahaya dan beracun (B3) begitu juga ditimbun, dibakar atau dibuang kelingkungan, karena mengandung bahan berbahaya dan beracun (B3) yang dapat membahayakan manusia dan mahluk lainnya, limbah bahan berbahaya dan bercun yang umumnya diterapkan oleh hukum. Beberapa metode penanganan bahan beracun (B3) antara lain :

1. Metode pengelolahan secara kimua, fisika, dan biologi

2. Metode pembuangan limbah bahan berbahaya dan beracun

\footnotetext{
${ }^{13}$ Ibid
} 


\section{Sumur dalam/sumur injeksi (deep well inkjection).}

Kemungkinan terjadinya kebocoran atau korosi pipa atau pecah lapisan batuan akibat gempa dan lain-lain sehingga limbah merembes kelapisan tanah, dan semua secara umum terjadi di kota Batam terhadap pengelolahan limbah bahan berbahaya dan beracun (B3) dan ini dilakukan pengawasannya oleh pemerintah dalam hal ini instansi yang terkait dengan lingkungan hidup, pemerintah dan masyarakat untuk upaya mengurangi tersebarnya bahan berbahaya dan beracun (B3) di wilayah kota Batam dan sekitarnya.

\section{Limbah Bahan Berbahaya dan Beracun di Wilayah Kepulauan Riau.}

Limbah Studge Oil yang berbahaya bertebaran di sepanjang wilayah dan atau pantai kawasan resort di wilayah Nongsa Pulau BatamKepulauan Riau. Hingga saat ini asal limbah bahan berbahaya dan beracun tersebut tidak dapat dipastikan dari mana datangnya, ada kemungkinannya aktivitas kapal di laut, mengingat Kepulaun Riau sebahagian besar wilayahnya adalah laut, yang langsung berbatasan dengan negaranegara tetangga lainnya. Limah bahan berbahaya dan beracun ini jika dimakan oleh ikan dan seterusnya dimakan lagi oleh manusia itu bisa menyebabkan gangguan pencernaan bahkan kanker. Peraturan Pemerintah Nomor 101 Tahun 2014 tentang Pengelolaan limbah B3 seperti Studge Oil yang tumpahan itu termasuk kategori 1 limbah B3. Limbah tersebut bahkan mematikan segala mahluk hidup yang ada di laut itu ditambah lagi kalau kalau membeku mudah terbakar, tapi kalau bercampur dengan pasir dan menjadi genangan di tepi panatai akan menghalangi udara yang masuk kelaut, ketika udara tidak masuk kelaut maka kehidupan di dasar laut akan mati, ikan-ikan tumbuh karang dan lainlain akan mati. Pembuangan limbah minyak hitam di pesisir wilayah kelautan di Kepulauan Riau ini sepertinya ritual tahunan karena terjadi setiap musin angin utara, sehingga ada yang menyebutnya Kepulauan Riiau sebagai tong sampah oleh pelaku pembuangan sampah berupa minyak hitam. Permasalahan tersebut limbah minyak hitam ini terjadi sejak beberapa tahun silam, keberadaan limbah tersebut berwarna hitam dan kenyal yang sangat mengganggu lingkungan hidup termasuk mahluk lainnya.

Aparat Gugus Keamanan Laut Komando Armada Laut 1 beberapa hari yang lalu menghentikan aktivitas penambangan pasir ilegal oleh PT X di Pulau Buluh Kabupaten Karimun, Perusahaan tersebut masih beraktivitas padahal sudah dikeluarkan Surat Penghentian Aktivitas Tambang Pasir di pulau tersebut sejak bulan Juni 2019 oleh Dinas Energi dan Sumber Daya Mineral (ESDM). Ini merupakan salah satu kerusakan lingkungan di pulau Buluh wilayah Kabupaten Karimun, karena pulau ini sebelumnya merupakan pemandangan yang indah. Berdasarkan Undang-Undang Nomor 7 Tahun 2008 Pasal 297 ayat (2) junto 339 ayat (1), kegiatan tersebut termasuk penambangan ilegal yang mengakibatkan sejumlah pulau disekitarnya rusak dan kemungkinannya bahaya lain juga bisa muncul seperti bahan berbahaya dan beracun (B3) bagi lingkungan dan mahluk hidup yang ada disekitar wilayah tersebut. ${ }^{14}$

Selain limbah seperti di atas, juga didapat limbah B3 Plastik dari perusahaan yang ada di Kepri terlebih di Kota Batam. Beberapa perusahaan plastik di kota Batam mengurus dokumen re-ekspor ke kantor Bea dan Cukai Batam. Pengurusan dokumen itu

\footnotetext{
${ }^{14}$ HarianUmum Tribun Kepri,29 Juli 2019, hlm. 6.
} 
menyusul desakan masyarakat dan Pemerintah Kota Batam akan bahaya limbah berbahaya dan beracun (B3) pada bahan baku yang diimpor beberapa waktu lalu. Kepala Layanan Pengiriman dan Informasi (BLKI) Kantor Bea dan Cukai Batam mengatakan bahwa beberapa perusahaan itu telah mengajukan pengurusan dokumennya untuk reekspor.

Limbah lainnya yang cemari wilyah perairan pesisir wilayah Kepulauan Riau, seperti yang disebutkan di atas (berupa limbah Studge Oil, limbah akibat penambangan ilegal yang ada di wilayah Kepri, limba plastik dan sejenisnya) juga masih di dapati pencemaran ditempat-tempat lainnya di Kepri seperti limbah akibat kegiatan nelayan yang mempergunakan alat tangkap yang dilarang oleh Undang-Undang bahkan melakukan menangkap ikan dengan cara memakai bom selain merupak tumbuh karang dan ikan, ikan yang terkena dan ikan tersebut dikonsumsi oleh manusia, maka bahaya bisa berakibat terganggunya kesehatan bahkan yang lebih fatal lagi ada menyebabkan kanker. Ini dilakukan nelayan daerah setempat maupun nelayan dari wilayah lainnya bahkan nelayan asing, baik yang dilakukan oleh perorangan maupun kelompok atau industri (perusahaan).Jadi selain merusak kesehatan mahluk hidup juga sangat berdampak kepada tatanan lingkungan dan mahluk hidup lingkungan lainnya, apalagi Kepri yang sebahagian besar wilayahnya yang berbatasan langsung dengan wilayah Negara-Negara lainnya.

\section{Upaya Pemerintah Kepulauan Riau tentang Limbah dan B3.}

Pemerintah Provinsi Kepri dan instansi yang terkait mengajak warga/masyarakat menjaga Laut dari Kerusakan dan bahaya B3.Laut bukan tong sampah, untuk itu pemerintah meminta masyarakat agar semua pihak tidak membuang sampah ke laut karena bisa terjadi pencemaran dan bahkan bisa menimbulkan bahan beracun dan berbahaya (B3). Kepulauan Riau yang luas lautannya sebesar $96 \%$ adalah sumber kehidupan. Kalau lautnya bersih, ikan dan biota lautnya akan semakin banyak, ketika sampah banyak mengapung, sektor pariwisata juga ikut terganggu, karena itu mari kita jaga laut agar selalu bersih dari sampah dan pencemaran dan bahan berbahaya lainnya.

Sehubungan hal di atas Menteri Kelautan dan Perikanan RI, Susi Pudjiastuti dan Pemerintah Daerah Provinsi Kepulauan Riau sepakat bahwa sektor perikanan dan periwisata akan membawa daerah ini makin maju, sumber daya ini harus tidak akan pernah habis kalau dijaga semua pihak. Periwisata dapat uang dengan memperindah, jaga keindahannya maka turis akan datang, kalau keindahan itu hilang, karangnya dirusak atau tercemar apalagi terkena dampak B3 orang datang hanya sekali.

Pelaksanaan Ketentuan Pasal 59 ayat (7) dan Pasal 61 ayat (3) Undang-Undang Nomor 32 Tahun 2009 tentang PPLH, kedua Peraturan tersebut sangat diperlukan pemerintah dalam pengelolaan limbah bahan berbahaya dan beracun (B3). Bahan berbahaya tersebut yang sifatnya objektif karena merupakan sisa atau usaha dan atau kegiatan yang mengandung Bahan Berbahaya dan Beracun (B3), makanya Peraturan Pemerintah 101 Tahun 2014 ini jelas dan dapat di pahami sebagai Pengatur Pencemaran Limbah berbahaya karena ia merupakan sisa usaha/kegiatan industri berupa zat, energi dan atau kumpulan lainnya yang kerena sifatnya konsentrasi, atau jumlahnya baik secara 
langsung maupun tidak dapat mengancam kelestarian lingkungan hidup, termasuk kesehatan umat manusia dan makhluk lainnya.

Menurut beberapa referensi dan pemerhati lingkungan hidup mereka mengklasifikasikan pencemaran limbah berbahaya ini ke dalam 3 (tiga) golongan yaitu :

a. Limbah bahan berbahaya dan beracun kategori 1

b. Limbah bahan berbahaya dan beracun kategori 2 atau

c. Limbah bahan berbahaya non B3.

Penglolaan bahan Bercun dan berbahaya (B3) tersebut seperti di atas pengelolaannya harus merujuk pada Peraturan Perundang-undangan yang ada mulai di gevaarlijke stuffen ordonnatie stb 1949 no. 337 serta sejalan dengan Peraturan Pemerintah No. 7 Tahun 1993 tentang pengawasan atau pendistribusian, penyimpanan dan pengguna pestisida sesuai SK Menteri Perindustrian No. 148/M/SK/1985. Dari berbagai Peraturan Perundang-undangan tentang limbah bahan beracun dan berbahaya (B3) setelah melalui uji karakteristik limbah tidak memiliki karakteristik dan atau sifatnya-sifatnya antara lain mudah terbakar, mudah meledak dan mudah reaktif. Pengendalian pencemaran limbah B3 bisa saja terjadi dalam pencemaran di air (laut) darat maupun di udara, kesemuanya merusak lingkungan hidup. (PP No. 101 Thn 2014), PP tersebut diharapkan dapat terlaksana dalam pengelolaan limbah bahan beracun dan berbahaya agar lingkungan itu berkurang dari segi pencemaran.

\section{Penutup}

\section{Simpulan}

Upaya pengelolaan pencemaran bahan berbahaya dan beracun (B3) di wilayah perairan perbatasan khususnya di Kepulauan Riau harus dilakukan secara sistematis, terpadu, melibatkan instansi yang terkait (pemangku kepentingan) dan masyarakat, agar wilayah perairan tersebut dapat mengurangi pencemaran dari bahan berbahaya dan beracun (B3) dan menjadikan lingkungan ini berfungsi dengan baik, terutama memberi manfaat bagi masyarakat dan nelayan yang khususnya yang berdomisili diwilayah tersebut yang mana sebahagian pencahariannya ada dilaut. Hambatan pencemaran limbah bahan berbahaya dan beracun (B3) di wilayah perairan perbatasan Negara di Kepulauan Riau antara lain adalah letak geografisnya (laut) lebih luas dibanding daratannya, dimana wilayah lalulintas kapal termasuk kapal asing yang segaja atau tidak sengaja menyebabkan kegiatannya terjadi pencemaran bahan berbahaya dan bercun (B3) begitu juga kegiatan nelayan termasuk nelayan asing yang melakukan penangkapan ikan secara melawan hukum, dan masih adanya ditemukan perusahaan termasuk perusahaan asing yang belum sepenuhnya mengikuti tata aturan lingkungan hidup.

\section{Saran}

Diharapkan para penegak hukum yang terkait, disarankan rutin melakukan penjagaan dan pengawasanwilayah perairan secara efektif ditambah keikut sertaan masyarakat menjaga keindahan laut agar tidak tercemar bahan berbahaya dan beracun (B3) yang dapat merusak lingkungan hidup itu sendiri danmakhluk hidup lainnya. 


\section{Daftar Pustaka}

\section{Buku :}

Arif Djohan Tunggal. Hukum Laut (Suatu Pengantar). Jakarta: Harvarindo, 2008.

Bambang Sunggono. Metodologi Penelitian Hukum Jakarta: Raja Grafindo Persada, 2015.

Drusteen, yang dikutip Muhammad Taufik Makarau. Aspek-Aspek Hukum Lingkungan. Jakarta: Indeks, 2011.

Muhammad Erwin. Hukum Lingkungan Dalam Sistem Perlindungan dan Pengelolaan Lingkungan Hidup di Indonesia. Bandung: Rafika Aditama, 2015.

Muhammad Taufik Makarau. Aspek-Aspek Hukum Lingkungan. Jakarta: Indeks, 2011.

R.M Gatot P. Soemartono. Hukum Lingkungan Indonesia. Jakarta: Sinar Grafika, 1996.

Rangkuti, Siti Sundari. Hukum Lingkungan dan Kebijaksanaan Nasional. Surabaya: Airlangga University Press, 1996.

Soerjono Soekanto. Pengantar Penelitian Hukum. Jakarta: UI-Press, 2010.

Takdir Rahmadi. Hukum Lingkungan di Indonesia. Jakarta: Rajagrafika, 2014.

Koesnadi Hardjosomitro. Hukum Lingkungan. Jakarta : Raja Grafindo Persada, 1986.

\section{Jurnal :}

Citra, Sukmadilaga, Good Governance Implementation In Public Sector: Exploratory Analysis of Government Financial Statements Disclosures Across ASEAN Countries, Procedia Social and Behavioral Sciences, 2015.

Jevlin Solim, Upaya Penanggulangan Tindak Pidana Penipuan Situs Jual Beli Online Di Indonesia, Jurnal Hukum Samudra Keadilan, Vol 14, No.1, 2019.

Zuhdi Arman, Tinjauan Terhadap Sistem Multi Partai Dalam Sistem Pemerintahan Presidensial Di Indonesia Pada Era Reformasi, Jurnal Cahaya Keadilan, Vol 6, No.1, April 2018. 
Volume 14, Nomor 2, Juli-Desember 2019

\section{Peraturan Perundangan-undangan :}

Undang- Undang Nomor 34 Tahun 2014 tentang Kelautan

Unang- Undang Nomor 6 Tahun 1996 tentang Perairan

Undang- Undang Nomor 32 Tahun 2009 tentang Perlindungan dan Pengelolaan Lingkungan Hidup

Peraturan Pemerintah No. 41 Tahun 1999 tentang Pengendalian Pencemaran

Peraturan Pemerintah No. 82 Tahun 2001 tentang Pengelolaan Kualitas Air

Peraturan Pemerintah No. 101 Tahun 2014 tentang Pengelolaan Bahan berbahaya dan bercun (B3)

\section{Internet :}

http://agroindonesia.co.id/2018/12/cegah-perubahan-iklim-pencemaran-lautharus-dikendalikan/, diakses pada tanggal 11 September 2019.

https://www.beritasatu.com/nasional/527425/tingkatkan-kapasitas-pengendalianpencemaran-laut, diakses pada tanggal 12 September 2019. 